\title{
The Shortage of Officers in the Army
}

\section{Major Lord Douglas J. C. Compton}

To cite this article: Major Lord Douglas J. C. Compton (1906) The Shortage of Officers in the Army, Royal United Services Institution. Journal, 50:340, 785-797, DOI: $\underline{10.1080 / 03071840609436388}$

To link to this article: http://dx.doi.org/10.1080/03071840609436388

\section{曲 Published online: 11 Sep 2009.}

Submit your article to this journal $\pi$

Цll Article views: 4

Q View related articles $\sqsubset$ 


\title{
THE SHORTAGE OF OFFICERS IN THE ARMY.
}

\author{
By .IAajor Lord DOUGLAS J. C. COMPTON, \\ 9th (Queen's Royal) Lancers.
}

WHEN one considers the difficulties which beset the organisation of the British Army, one can only feel astonishment that its numbers and efficiency are kept up as well as they are. With the country ruled by a representative government on party lines, and the Army managed by a civilian-a member of the party which happens to be in power-it is, to say the least, severely handicapped.

Perhaps the most difficult problem which successive Secretaries of State for War have to deal with is the supply of recruits, which, being entirely dependent on the popularity of the Army at the moment, must always be an uncertain quantity.

Matters have, to some extent, improved of late, but except at the moment when we are engaged in some war which appeals to the public fancy, the country cares little, and knows less, about the Army. Those who join its ranks do so because it suits their taste, or because they are driven to it by want of employment. There is no feeling that it is in any way a duty to devote even one member of a family to the service of his country; on the contrary, there is still a rather general feeling that the lad cnlists because he is incapable of making his livelihood in any other way.

Secretary of State follows Secretary of State, and cach one takes up the office apparently full of confidence in his ability to put things on a sounder basis. Each one produces schemes by which he proposes to give the country more men for less money; some even succeed in cutting down some avoidable expenses, and then, having raised the soldier's pay a penny a day, imagine that recruits will come pouring in; but each one retires from office discredited (often unjustly), and a new man commences to undo a system which has cost years of labour to start. Meantime, the Army muddles on in the same old way.

Soldiers-who, after all, should be the best judges-are generally of opinion that there is no way to mend the matter except by some form of conscription; and that it would mend matters there can be little doubt. Think of the difference that even the most limited form, which need scarcely be called conscription. would make. Suppose cvery male in the United Kingdom, who did not elect to serbe in the Regular Army, or in the Imperial Yeomanry, or Volunteers, for a certain number of years, were compelled to serve in the Militia, so many months' training for so many years, what would be the result? The supply of recruits for the Regular Army, the Volunteers, and the Yeomanry, would be immediately increased;' every male in the kingdom would receive sufficient training to enable him to take his place in the ranks in the event of war, and the country at large would get to know more and care more about its Army.

vor. $\mathrm{L}$. 
So much for the benefit which would accrue to the Army, but the country itself would benefit almost as greatly from its entire manhood having had to underge a term of discipline and training.

It is a simple solution of the difficulty, and the more one looks at it the more one is attracted by it. There is only one argument against it, and that is, that those who rule are quite certain the country will not have it. As long as that is so we must make the best of present conditions; attract the recruit to the Regular Army by increased finery and pensions (not cubicles and "higher pay"), attempt to arouse the country to some interest in its Army, and by means of rifle clubs, and military cadet corps, give the manhood the first necessities of a-military training.

But to counter-balance whatever improvement there is in the matter of recruiting for the rank and file, there is a new difficulty now arising - if it has not already arisen-as serious, or more so, than the difficulty of obtaining recruits-for the ranks; I mean the shortage of officers. In these days it is difficult to open a paper or magazine without seeing articles or letters on officers' expenses, the education of officers, the shortage of officers, ctc.; but these are mostly written by civilians, or, if by soldiers, by those who have long ceased to be regimental soldiers; so, perhaps, it will not be amiss for a regimental officer, who has spent the last twenty years in constant companionship with regimental officers, to write of the matter as it strikes them.

First, it will be as well to enquire what exactly is meant by the shortage of officers. We read of the successful competitors at the examinations for Sandhurst, 1 and we hear how keen the competition is to gain admission to that college, and yet an enormous number of regiments are without their full complement of officers, and, if rumour speaks truly, there are, at the War Office, a large number of officers' resignation papers sivaiting acceptance. The fact is, that the number of cadets who can be accommodated at Sandhurst, and passed from thence into the Army, is at present insufficient to fill the number of vacancies caused by officers leaving the service.

One simple remedy for this would seem to be to-increase the size of Sandhurst, so as to pass into the Army the number required to fill vacancies; and if we could be sure that the increased number of officers who are leaving the service each year are not those whom it is desirable to keep for the good of the service, this plan would have its advantages. Promotion would become quicker for one thing, and it seems to be universally accepted that in these days the vast majority of officers are too old for their jobs. There are, however, difficulties in connection with this plan. First, it is hard to say how many of the unsuccessful candidates at the competitive examination for entrance to Sandhurst do not subsequently pass in, or else go into the Army through the Mifitia. It is only by the actual surplus-that never get into the Army at all-that the number of our bfficers would be increased were Sandhurst-enlarged, and the competition for entrance consequently lessened; the numbers of this surplus are probably small, and a simpler method of attaining the same object would be to increase the number of officers who are let in from the Militia. Secondly, there comes the question of obtaining officers for the Guards

${ }^{1}$ As the Rosal Artillery and the Royal Engineers are not suffering from shortage of officers, Woolwich can be left out of the question. 
and the cavalry, which, costing as they do more than other regiments to live in, can only be filled with officers desirous of going to them: Lastly, however successful may be the means taken to fill up the quickly recurring vacancies, the very fact that there are now difficulties in the way of officering the Army which liave never existed till lately, proves that "there is something rotten in the state of Denmark." This-whatever it is - shotld be remedied, as the disease is catching, and one that spreads rapidly. Officers, both those in the Army and those who have left the Service, tell the younger generation their opinion of it. When many officers are leaving because they are dissatisfied with the conditions of the service, one may be sure that their opinion will have its effect on the boys who are making up their minds what profession to adopt. That this is actually the case at present is brought home to one again and again. Only a few years ago, when a soldier was asked what he was going to do ivith his son, the answer was generally the same: "Oh, put him into the regiment; he won't make money, but he'll have a $d-d$ good time." Now the answer is generally: "Well, I don't know, but he's not going into the Service," and the most frequent variation to that is: "He's going to be a sailor." Why the Navy should now be more popular than the Army it is hard to say, unless because it is generally conceded to be a better run show, and because in it boys get a chance of having their own command, and showing whether they are worth anything before their hair is grey. Whatever the reason, there can be no doubt that the Army is at present becoming unpopular, and consequently suffering from a shortage of officers, and unless steps are taken to make the Army regain its popularity, matters will grow steadily worse.

It is constantly stated that the reason for this dearth of officers is that the pay is too small for the work that is now expected of them, and this is quite true as far as it goes; but the only remedies that are suggested are to decrease the expenses of living in the Army, and to increase the pay, principally the former.

Now it appears that decreasing the expenses of living in the Army-in the way in which it is done-far from attracting more officers, or deciding those already serving to stick to the service, is one of the principal causes of the present shortage. Decreasing officers' expenses almost invariably takes one of two forms: either to interfere with and attempt to limit the ways in which officers spend their money, by prohibiting regimental races, a regimental drag, regimental polo tournaments (this, I am glad to say, has not yet been done, though often proposed), regimental entertainments, etc.; or by making some change which at first sight appears to be a saving, but which almost invariably proves to be really an extra cxpense to the officers themselves, the saving-if any-being to their parents or guardians when officers originally join, and the State generally making a bit over the transaction. I allude to such changes as the supplying by the State to officers of furniture and of chargers, and also all changes in uniform. The only advantage gained is that "Paterfamilias" cannot write so many complaining letters to the Times, which he probably enjoved doing.

The money made by the State on furniture and chargers leased to officers is, I feel sure, quite unintentional, and is too little to bo counted as an advantage, but the idea that the State should make any is an additional annoyance to the officers. 
The only way in which expenses could be cut down so as to really benefit officers, would be by giving them furniture, chargers, uniform, etc., and that would cost the State money, and would not be such a satisfactory method as giving the officers more pay.

As regards increasing their pay, there is some talk of doing so now; and undoubtedly any increase in pay is an advantage which will be thankfully received, and will.be likelv to induce more to join the service and to remain longer in it. It is, however, out of the question for the State to enter the Army into competition with others as a lucrative profession, and without that we must be content to recruit our officers from those who join the service because they havo a taste for soldiering, or because their circumstances induce them to do so.

There remains one remedy-which is never suggested-and that is to reduce the amount of work which officers now liave to do, and to take other steps to make an officer's life in the Army as pleasant as it always used to be considered.

At first glance this appears to be too absurd and unsound a remedy to be seriously contemplated. For years there was an outcry over the want of education of our officers, until at last means have been taken to make officers work harder; and one can imagine the outcry at any suggestion of reverting to the old system. But is it certain that the proper means have been taken to make officers more efficient? Are our staff officers as efficient as they should be? Have we enough of them trained? And are our regimental officers any better educated, or any the better officers than they were 20 or 30 years ago? Soldiers generally answer all these questions in the negative.

The system at present is by multiplying examinations, and increasing the difficulty of them; to make each individual officer work either by himself, on at his own expense with a crammer; and by increasing the amount of drill and mancuvres for troops, and insisting on all officers being present, to cut down the amount of leavo obtainable, and keep them constantly with their noses to the grindstone.

It is to this. system that is due to a great extent the present uupopularity of the Army as a profession. If the system were sound; the consequent unpopularity of the Army would have to be accepted, and other means taken to procure the officers required, but is it sound? - Again officers themselves answer with a decided negative. The late Colonel Henderson, whose views on the training of British officers are perhaps more worthy of-attention than those of any other man, living or dead, writes of the British officer of $1899:$ - "It is to be remembered that even the idlest was not altogether an unwholesome subject. The unattractive and unpractical nature of his training in the United Kingdom or the Colonies was at the root of his apathy. Nauseated with dull theory, cramped by the hant of responsibility, his energy unawakened by appeals to his intelligence, with no opening offered to him to acquire that higher knowledge which would have aroused his interest and kindled his ambition. . . " What Colonel Henderson wrote of the officer of 1899 , applies with equal force to the officer of 1905, and if.it is admitted that the increased amount of work required of officers has not made them more efficient, and that the system is not sound, it becomes natural to enquire whether it is not possible.to increase the popularity of the Army by reducing the quantity of work, while, at the same time, 
increasing the efficiency of the officers by improving its quality, and the facilities for learning it.

Before proceeding further, it would be as well to consider what are our requirements in the way of officers, and what there is provided from which to supply those requirements.

We require two sorts of officers: regimental and staff. - Considering first the regimental officers, we require men who are accustomed to command and to obey, who have an intimate knowledge of drill, of manouvre, and of their men, and a knowledge of tactics and of strategy, increasing as they rise in rank. They must be active, fearless, self-reliant, brain and body sound and fit, ready to accept responsibility, quick to take in a situation, or seize an opportunity. and they must be gentlemen. For staff officers we require men who are much more highly educated in all military matters; they must have all the same qualities as regimental officers, indeed, they will have to be regimental officers themselves for a large part of their service; but besides" all this, they must have their brains stocked with every kind of knowledge of military routine, organisation and equipment, movements of troops, camps, etc. Their knowledge of tactics and strategy should be greater than that required of a regimental officer of the same rank, they should know something of fortification ani topography, and they should be possessed of infinite patience and tact. In short, they should be pattern individuals with universal knowledge.

Of these two classes-regimental and staff officers-we want a very much larger quantity than we have ever had. Wo want not only enough to fill the staff billets, and to officer our regiments up to full strength in peace time, but a reserve which will be ready in time of war; a quantity of officers serving with their regiments ready trained, and fit at any minute to take up staff duties; a quantity of officers not serving with regiments in peace time, but ready trained and fit at any minute to take up duties as regimental officers, and fill up the place of those taken to serve on the staff, and vacancies caused by sickness and death.

To supply these wants we have a very large number of lads anxious to go into the Army who can be divided into two classes:-

1. Those who mean to make a profession of the Army, and are anxious and ready to do any amount of work, with the intention of soldiering all their lives, and the ambition to become great soldiers.

2. Those who go into the Army for a term of years only; with no ambition ever to rise higher than the command of their regiment; and in this class is included many elder sons, heirs to property and means, who never intend to soldier for lunger than a few years.

Now it may be and very often is-said that the regimental officer should be a much more highly-educated individual than I have here indicated, and that the: second class of officer recruits, spoken of above, consists of just those that are not wanted in the Army. "Wo want professional soldiers; not amateurs," has become a sort of catchword, used as glibly, and with as little meaning as invectives against "red tape" or demands for "military efficiency." With reference to the education of the regimental officer it is a question open to argument whether it is advantageous to educate anyone above their station in life, and in any case it is impossible to entirely officer 
the Army with embryo generals. Why should a man who spends only ten years in a particular profession-or only one for the matter of that-be dubbed an amateur? In the history of our Army the regimental officers have been by no.means the class who have shown up worst, and they have always, to a large extent, consisted of theso very men who have no ambition to rise to anything beyond. This is, perhaps, especially the case in the Guards and cavalry. How do these corps compare with other regiments? The cavalry it is difficult to compare with anything except themselves, but those regiments called "crack," to mich go as a rule those very elder sons, and men of means, who never intend to soldier more than a few years, are, generally speaking, as much better regiments than others for soldiering, either on service or in times of peace, as they are on the polo ground, or in the hunting field. The Guards I have heard spoken of by staff officers - not Guardsinen - as an example to infantry regiments of the line.

Now it is in these very corps-of the Guards and the cavalrythat the present shortage of officers is most apparent, and thus it is seen that if the Army is better without the second class of officer recruits spoken of above, the present system is the very one likely to get rid of them. But what is the result? Up to the present, far from anything better having been produced to take their place, nothing at all-better or- worse-has been found, and their places remain vacant. It is surely incontestable that the old class of regimental officer is better than none at all.

The question, then, is how to make the supply of officer recruits meet our demand to the best advantage in the way of staff and regimental officers, and the answer which most officers will give is:Insist on work and proficiency up to the point where officers become good regimental officers and no further, but give every facility to all officers who wish to do so to study particular and the higher branches of their profession.

I have already alluded to the way in which the present system seems to consist in making rork for officers to do, and to be devised with the intention-if any-of attempting to make every officer fit himself for the highest posts; but I lave not yet-spoken of the facilities afforded to officers-who wish to do so-of studying the higher branches of their profession. What are the facilities? When one considers for a moment, they seem to be conspicuous by their absence. It is so difficult to get into the Staff College that that course hardly comes under the heading of facilities. The study of any subject an officer wishes to learn has to be made in his own time, any assistance at it has to be paid for out of his own money, and at present every effort seems to be made to leave him less time of his own, and to officer the service with men with less money of their own. Officers are certainly paid some reward after passing examinations in foreign languages, but in most cases the reward does not cover the expense incurred in learning them, and for no other branch of learning are they paid any compensation at all.

But if there are no actual facilities for study afforded to officers, there are, at any rate, besides the Staff College, certain classes to which they can go to learn various matters connected with the soldier's profession, sucl as musketry, signalling, veterinary, pioneer, transport.

To begin with the Staff College-granting that it is a most excellent institution, well fitted to give the regimental officer the training 
he requires in the theory of a staff officer's work, and of the higher branches of the military profession, still, it is much too small; so small that the limited number of officers who can attend each course have to be selected by a competitive examination, a very severe one from the fact that there are so many men competing for so few vacancies.

Now, if officers are to be given every facility for studying the higher branches of their profession, and for fitting themselves to be staff officers, there should surely be no question of a competition to be allowed to so study. The Staff College should be open to all. All should be invited and encouraged to go. Of course, officers commanding units would first have to recommend candidates as being proficient in regimental work and likely to make good staff officers. If considered necessary, there might be a pass examination before officers were admitted. These checks would keep the numbers within limits, as colonels would not be able to spare more than one or two of their officers from - their regiments at a time, and the pass examination might be made to require sufficient ability and industry to prevent any officer from using the course merely as a "shunt," by means of which he could escape service in some unpleasant station.

Another regulation which prevents officers from going through the Staff College course is that which limits the age for entrance to 36. This again seems difficult to understand. There are many cases in which officers are prevented by foreign or active service, or other causes, between the ages of $25^{1}$ and 36 from ever working for the entrance examination, any chance of success at which means for most men a good many months' hard work with a coach or crammer. Why should the officer of 36 be debarred from that assistance in the study of the higher branches of his profession which is given to his more fortunate junior?

If the Staff College is only intended to teach subalterns and captains the duties of junior staff officers, then it would appear that another institution would be desirable, at which all officers-at any rate, up to the rank of second-in-command-could study_the higher branches of the military profession.

However, if all officers who wished, and who were recommended by their commanding officers as fitted, were permitted to go through the Staff College course, without any question of competitive examination, perhaps there would be no necessity to alter the age limit.

Now, if this suggestion were carried out, that is, if the Staff College were enlarged; and all officers encouraged to go, what advantages would there be to compensate for the extra expenditure?

In the first place there would be a far larger number of trained staff officers available in time of emergency.

In the second place; the efficiency of the staff officers would be increased, as it would be possible to select the best from those who had passed through the -Staff.College; and here it may be noted that, though undoubtedly the Staff College does what it claims to do-that is, sends away the officer, after having completed the course, more efficient than when he started it-yet both the Army and the reputa-

1 Officers must hare fre years' service before they can go to the Staff College. 
tion of the Staff College suffer from the fact that it is by no means always the officer most likely to make a pattern staff officer who goes through the course. The reason for this is the difficulty of the competitive examination, which chokes of many ambitious soldiers. Excelling in competitive examinations is a gift by itself, and is, moreover, a gift which does not by any means necessarily go with aptitude for either staff officers' work or for high command. Under the present system it principally those who possess this gift who go to the Staff College, whence it follows that many of our staff officers and of those holding high command-including some of the mast able-liave never boen through the Staff College, though there is little doubt that they would have benefited by doing so.

If it was made easy for every officer, who had ambitions beyond regimental soldiering, to go through the Staft College course, it would be possible to enforce the rule that no officer. should hold any staff appointment till he had been through the course, and also to make every officer do a term of soldiering with his regiment between each term of staff service, say two years with his regiment after three years' staff service; this would keep staff officers in touch with regimental soldiering, which would certainly increase their efficiency, and would also ensure a larger number of officers having practice in staff work, which is at least as necessarv for their efficiency as that they should have been properly trained in the theory. -

In the third place, all these oflicers would have served a term with each of the other arms besides their own, as this is part of the Staff College course. To have done this is so beneficial to all officers holding independent commands, that unless thcy do it as part of the Staff College course, it would be advisable to allow all officers-say of the rank of major-to serve for one drill season with each of the other arms.

In the fourth place, we should have a larger number of officers on the active list, as all the officers actually at the Staff College would be seconded, and their places in their regiments filled up. That we require a larger number of officers has already been demonstrated, and while we have a very small Regular Army, and rely on the Auxiliary Forces to swell its numbers when occasion demands, the necessity for a large surplus of trained officers is all the more urgent.

In the fifth place, something would have been done to make officers more content with the conditions under which they serve, and to increase the popularity of the Service.

As regards the various classes-most of them optional-which officers can attend to learn certain subjects, it does not come within the scope of this article to criticise the way in which these classes are organised or managed. They are generally accepted as being excellent, bui a knowledge of the subjects taught at some of these classes is required of every officer, whether he has been to the class or not, and $a$ knowledge of many subjects is required, to teach which there are no classes. Every officer should of course go through the musketry class. Garrison classes had also an obvious purpose-to prepare officers for their examinations for promotion; it is hard to see why they should have been done away with. The result of their abolition is that officers pay a crammer to help them to pass these examinations; thus they are put to extra expense, which is contrary to the system of reducing expenses, and destroys the intention of the examination, 
which is presumably to ensure that they should do some useful work, and prove their knowledge of necessary branches of military science. Work got up hurriedly with a crammer for examination purposes, and consequẹtly forgotten directly after, cannot be said to do either one or the other. At a garrison class at least an attempt could be made to teach an officer what he ought to know in a useful way.

The signalling of the Army is a pattern of the way in which all such departments should be managed. The class for it is voluntary, so that only officers who wish to learn signalling, or who are selected by their commandilg officer as likely to make a good instructor for the regimental signallers, go through it, and knowledge of signalling is not required of officers who have not been through the class. Yet I do not think it is ever suggested that the signalling of the Army is not up to the mark, or would be improved if all officers were obliged to learn it. Signalling is as important for the Army as topography or field engineering. Why should not tho same methods be applied to trem? The point to be noticed is that signalling is almost the only branch of military science which we treat entirely on the system of training experts to conduct it, instead of making it part of the stock' of the Jacks-of-all-trades into which we try to convert our regimental officers.

As regards engineering, there is a cavalry pioneer class and an infantry pioneer class, to which officers can go to learn sufficient of the theory and practice of military engineering to instruct the regimental pioneers in bridging, hasty demolitions, entrenching, étc. So far excellent; but the raison l'être of the class is rather destroyed by the fact that every officer is required to pass an examination, for promotion, in the same subjects without going through any class at all!

For topography there is no class, but all officers have to pass in this subject also, in their examinations for promotion. It will be readily submitted that every oficer must be able to read maps, and must know how to use a compass; but if we say that no amount of teaching will enable more than one out of every three officers to draw a military sketch which will be of any use, I think we shall be well within the mark." Surely this is a subject for experts, and should be taught to classes of those anxious and able to learn how to make maps. - Of the others, nothing more should be required than that they should be able to read and work by them.

Then there is a veterinary class, which is optional, and at which no more is taught than what is already known by every officer who has had much to do with horses. Now, every cavalry and horse or field artillery officer should know more than this of veterinary science. It is a subject, moreover, which every officer could learn. It would therefore appear to be advisable to go further into the subject at this class, and to compel every officer of a mounted branch to go through the class.

The transport, supply, and gymnasium classes are to teach officers extra regimental work. We are not liere concerned with them, but the system on which they are worked appears to be the correct one, and the general system which the foregoing remarks lead up to is this :-

1. That there should be classes to teach every branch of military science which will bo useful to officers. 
2. That in subjects such as musketry, tactics, strategy, and (for officers of mounted branches) veterinary, of which all" officers can and should acquire a knowledge, it should be compulsory for all to attend a class and gain a certificate.

3. That in subjects such as signaling, field engineering, and military sketching and surveying, of which all officers are unable to acquire a knowledge, and for which only a certain humber of experts are required, attendance should be voluntary, and no officer, except those gaining certificates at the class, should be required to have any knowledge of them.

It may be said that all officers must have some knowledge of topography atd field engineering, and that the only question is exactly up to what point that knowledge is required. That does not affect the argument, which is that an expert's knowledge is required of a ferv, and very much less of the rest. Under the present system we have no experts, and require more than is necessary from all-certainly much more than all are capable of doing to advantage.

Enough has been said to show how the examinations for promotion required of all officers might be simplified. Map reading and such elementary topography as was conșidered necessary for all, as also the methods of obtaining cover quickly, either by digging or sangars-which would be practically all the field engineering necessary for every officer to know-could be included in the $a$ and $b$ part of the examination. The knowledge of military law required might remain unaltered, or rather more time might be given for the paper for which books are allowed. As arranged at present, it is nearly impossible to look up in the timo everything in the book which is presumably the intention of the paper. Examination in organisation and equipment-a deep knowledge of which is only useful to adjutants and orderly-room sergeants-might also be confined to a paper to be dono with books, so as to ensure officers knowing where to find the answers. to any questions which might possibly present themselves; such Army organisation as every officer should know will always come under the heading of Tactics. The examination in tactics and strategy should not be reduced at all, but there should be compulsory classes at which officers would be taught those subjects.

There remains the question of leave. From time immemorial subalterns (and their seniors, too) have taken as much leave as they could get, and their commanding officers have kept this amount within reasonable limits. That system worked very well. Twenty years ago, and before that, young officers got very little leave beyond their ten weeks-as often as not curtailed to two months-in the year. But then offices s could always get away for a day or two if there was nothing particular going on. Out of the drill season such work as was necessary was arranged so as to allow officers to get away and hunt, or even shoot, two or three days a week, and even in the drill season, after the work of the day was over, an officer could go anywhere he pleased as long as he was back in time for the work of the next day. Where was the harm in that? If an officer chose to spend his night dancing in London between two field days at Aldershot, he may have been rather sleepy during the second, but certainly no more so than he was again and again on service in South Africa or elsewhere, when he lad marched during several nights, and marched and fought 
on the intervening days: Now, at any rate at some stations, that has all been changed. In at least one brigade at Aldershot a year or two ago it was forbidden for any officer to spend the night away. from Aldershot during part of the drill season, and this not at a time when there was any particular reason to account for the order. Those are the sort of orders which annoy and disgust officers. They will do any amount of work that is required of them, and won't even grumble if they know that the work has an object and must be done; but when their privileges-the way in which they spend their spare time and their spare money-aro interfered with, they begin to say it is not good enough, and one day something annoys them more than usual, in go their papers, and the services of another (quite possibly promising) officer are lost to the country.

Officers give to their country the greater part of their time and the best work they are capable of; they are prepared to spend the best years of their lives in horrible countries with pestilential climates, and they are ready and eager to risk life and limb in the service of their country at any moment. This they do for a miserable pittance of pay, and then they are often treated like naughty schoolboys! Perhaps it is this treatment as much as anything else which causes the present shortage of officers.

Returning to the question of leave, the simplest and best system on which to work seems to be to insist on every regiment having a certain number of officers present with it-the number laid down varying according to the season of the year and the work' on which the regiment is engaged-and leaving the rest to the officer commanding it. He knows which of his officers know their work and can be spared, and which of the juniors are fit to take the place of seniors who are away. There is always this to be said in favour of leave, and it is a very strong argument, that if the seniors are never away their juniors never get a chance of practising the work of the rank next above them. The battalion which has had all its company leaders present throughout a drill season will undoubtedly make the best show at a field day or inspection at the end of it; but send it on service, and a few weeks later. when half the company leaders have gone, owing to casualties, staff employment, and what not,-then the subalterns commanding companies in their places (yes, and their colonel too) will wish that they had had a little practice as well as example at the job in peace time.

There is a mean between the extremes in the leave question as in every other, and it is equally absurd to allow young subalterns, who do not know their work, to have as much leave as they care to ask for, and to refuse leave to an old captain or major who has spent the best part of his life soldiering under all conditions, because it happens to be the drill season.

This suggests another method of increasing our reserve of officers. That is, to grant to officers who are recommended by their commanding officers as knowing their work thoroughly well, who have served, say, two years in their present rank, and have passed for promotion to the next senior rank, one, two, or even three years' leave, during which they will draw no pay, be seconded from their regiments, and their places filled up. Mrany officers would avail themselves of this privilege when they were contemplating leaving the Service altogether, and of those a good many would ultimately come back instead of leaving. To grant leave without pay to others who have a craving for exploring 
some country or shooting big game. To others, again, whose business affairs demanded a lengthy stay in England while their regiments were abroad. Of those who took this leave many would come back the better officers for having seen other countries, or met and mixed with other men besides soldiers. It would only take a month or two on their return to rub up their military knowledge, and make themselves acquainted with the changes that had been made during their absence, and they would be just as useful regimental officers as ever they. were. If the contrary is argued, it can be replied that already officers on foreign service are allowed as much as a jear's leave; some officers go on personal staffs of Viceroys or Governors for five years, sometimes more, during which time they do no soldiering; others are seconded from their regiments on becoming Members of Parliament, and others, less fortunate, are placed on half-pay, when, owing to sickness, they are unable to serve for a considerable time. I have never heard it said in any of these cases that the officers have been less efficient afterwards, nor that others grumbled at their coming back to their old places in the regiment.

If this privilege were granted, not only would many officers remain on in the Service. who would othervise leave it, but also every one of these officers away on long leave would be one more added to the reserve of officers so urgently needed. It is not difficult to imagine, in the event of war, how these would swell the numbers besieging the War Office and beseeching to be given any job which would take them to the front.

It is easy to foresee the criticisms which will be made on the system herein advocated. Doubtless it will be said that what has been suggested is to have a class of professional staff officers and a class of amateur regimental officers, and to give them all the same pay and rate of advancement. To this it may be answered that the intention is to have a class of professional staff officers and a class of professional regimental officers, instead of all being more or less Jacks of-all-soldiering-trades. As regards the pay, it is so inconsiderable for the junior ranks that it had better be left out of the question. The State could never afford to compete as a paying profession with the Stock Exchange or "business," and the fact that nowadays so many gentlemen do go into the City or into business is one of the causes of the actual dearth of officers. As regards advancement, the present system, simply stated, is advancement by seniority until an officer comes on the staff of the Army, and advancement by selection after that. There are, of course, exceptions to the rule, as when an exceptionally able officer is offered promotion into another regiment, or when an exceptionally inefficient officer is passed over for promotion, or advised to retire from the Service. This rule, with its exceptions, cannot well be bettered, because under it the really clever, efficient, hard-working officer gets advancement as it is, and would probably do so even more if facilities were given him for studying his profession, as suggested. Moreover, he is the one who would ultimatelv rise to the top, whereas the man who never attempts to be more than a regimental officer will never rise higher than the rank of Lieut.-Colonel, if so far.

To recapitulate:-

1. Insist only on officers doing the work necessary to make them thoroughly efficient as regimental officers, but give every facility for, and encouragement to, all officers to study the higher and all branches of their profession. 
2. Enlarge the Stafi College, abolish competitive examination for admission to it, encourage all officers recommended by the oflicer commanding their unit to go through the course, and make no exception to the rule that after a term of staff employment an officer must serve a term witi his regiment.

3. Adopt a system of specialists for all branches of military science which it is not necessary for every officer to know, such as signalling, field engineering, and military sketching, giving any officers who wish, opportunities of attending classes where these subjects are taught.

4. Insist on the number of officers really required being present with their corps, and leave it to the officers commanding units to grant leave to the surplus as they think fit.

5. Avoid all interference with the way in which officers choose to spend their spare time and money; there are many easier and more unwholesome ways than playing polo, driving a drag, or even giving a ball. The most that should be done is to insist that all subscriptions to regimental clubs, entertainments, etc., be voluntary, with the exception, of course, of those of mess, band, and furniture funds.

6. Remember that cliange is in itself $a$ bad thing in the Army, and that changes should only be made when the good to be gained distinctly outweighs the evils of changing. 